\title{
BASIC PARAMETERS FOR DESIGNING PHYSICAL SEPARATION TREATMENTS FROM AN INTENSIVE ON-SHORE FISH FARM
}

\author{
Biagio Bianchi, Gerardo Centoducati, Francesco Toteda, Onofrio Nardomarino
}

\section{Introduction}

There are many factors which may influence the metabolic activity of the fish reared and therefore the characteristics of the pollutant load in effluent and intensive plants [Boyd 1990] for example: the fish species reared, stocking density, water renewal, the quality of incoming water, the type of tank used [Ross 1995].

Many studies highlighting levels of chemical and physical effluent parameters give very different results concerning total pollutant load $\left(\mathrm{COD}, \mathrm{BOD}_{5}\right.$, Total Suspendend Solids) [Bianchi 2004] the greatest differences are found between the results of research carried out in pilot or small-scale plants [Dumas 1998] and those obtained from industrial farms [Jones 2001]. Industrial farms often produce effluent water which is too highly polluted for discharge into surface waters and which may even contribute to eutrophication [Ziemann 1992; Dosdat 1994]. In many cases a correlation has been found between the concentration of suspended solids in the effluent and the total pollutant load, especially when this consists of organic matter [Jones 2001; Suresh 1992].

Research carried out by the PROGESA Dept. of the Faculty of Agriculture, University of Bari in an intensive closed-cycle plant for growing out bass ( $\mathrm{Di}$ centrarchus labrax) and gilthead (Sparus auratus) in the Lower Salento (Lecce Province) has shown oper-

Paper received 23.07.2010; accepted 08.12.2010

Prof. ing. BIAGIO BIANCHI, biagio.bianchi@agr.uniba.it, associate professor, DISAAT Dept., University of Bari, via Amendola 165/A, 70126, Bari (Italy), Tel./fax + 390805442940 .

Prof. GeraRdo CentoduCATI, gerardo.centoducati@veterinaria. uniba.it, researcher, Dept. of Public Healt and Animal Science, University of Bari.

Prof. FrANCESCO TOTEDA, toteda@agr.uniba.it, associate professor, Dept. of Animal Production, University of Bari.

Dott. agr. ONOFRIO NARDOMARINO, onofrio.nardomarino@alice.it, Officer in charge of quality control, Giuliano s.r.1., Turi (BA).

Prof. B. Bianchi co-ordinated the research and the experimental trials, processed the results and wrote the paper; Prof. G. Centoducati contributed to the co-ordination and carrying out of the experimental trials, and to processing the results; Dr. O. Nardomarino, contributed to the carrying out of the trials and to writing up the paper; Prof. Toteda did the statistical analysis of the results. ating conditions which require purification of effluent with pollutant load peaks consisting of high concentrations of suspended organic matter, and a high $\mathrm{BOD}_{5} / \mathrm{COD}$ ratio [McIntosh 2003]; in the same effluent over $70 \%$ of suspended solids were found to consist of particles with a maximum dimension greater than $100 \mu \mathrm{m}$ [Bianchi 2004].

The same study revealed that a mechanical filtration treatment was adequate for the specific requirements of the plant, because it can be adapted to seasonal variations in pollutant load, thus making it possible to reduce the pollutant load in accordance with legal restrictions and also to allow energy consumption not to exceed $3.9 \mathrm{~kJ} / \mathrm{m}^{3}$ of treated waste water [Bianchi 2004].

Kevin, Wong and Piedrahita [Kevin 2000] used a top-loading settling column to characterize the settling properties of the solids in the discharge water from a commercial rainbow trout production facility; in this paper it is underlined that settling characteristics of aquacultural solids will vary from facility to facility and it is suggested that a sedimentation basin should be designed with an overflow rate of about $0.5 \mathrm{~cm} \mathrm{~s}^{-1}$ or lower, in order to capture about $80 \%$ of the settleable; moreover a method useful to perform a similar type of analysis at other aquacultural sites, which may be growing other species under different management regimes is described.

The present work reports the results of a study which aimed to characterize the effluent water produced by an intensive bass and gilthead growing out farm; the goal was to acquire experimental data about the pollutant load produced when the farm was operating in the most potentially polluting conditions and to define design criteria for a purification treatment which should be suitable for this kind of effluent.

In Italy, the chemical and physical characteristics of industrial waste discharged into surface waters are defined by Italian laws (D.L. 3/3/2006 n. 152, G.U. 14/4/2006 n. 88 - S.O. n. 96; D.M. 7/4/2006, n. 152, G.U. 12/5/2006 n. 109 - S.O. n. 120) which reiterate EC Directive 91/271 concerning the treatment of urban and industrial waste water, and EC Directive 91/676 concerning water pollution by nitrates used in agriculture (Tab. 1). 


\begin{tabular}{|c|c|c|c|}
\hline Pieanteser & $\begin{array}{l}\text { unik of } \\
\text { metiourtment }\end{array}$ & $\begin{array}{l}\text { Escharye inlo } \\
\text { surface walers }\end{array}$ & $\begin{array}{l}\text { Eicharges } \\
\text { inco sewnges } \\
\text { of sents }\end{array}$ \\
\hline $\mathrm{EH}$ & & 5.5 .95 & 3.5 .95 \\
\hline fecal portisles (Escherichio coli) & UFCiso $\mathrm{ml}$ & $\begin{array}{l}5000 \\
\text { (rourunknidd } \\
\text { sinit) }\end{array}$ & $\begin{array}{l}5000 \\
\text { frearntandad } \\
\text { Emos }\end{array}$ \\
\hline now makerials & & dewent & ubsent \\
\hline hail suapendend solis: & mest & $\$ \$ 0$ & 3200 \\
\hline $\mathrm{BOD}_{1}\left(\mathrm{O}_{2}\right)$ & mpll & $\leq 40$ & 5250 \\
\hline $\operatorname{COD}\left(0_{t}\right)$ & mol & $\leq 160$ & 560 \\
\hline Active Chiorine & mgl & 90.2 & $-0,3$ \\
\hline Sulphide (S) & mgl & 51 & 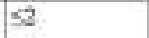 \\
\hline Salphice $(90,3)$ & mel & $\leq 1$ & 2 \\
\hline Sulphase $\left.\left(9 O_{1}\right)()^{\circ}\right)$ & mpi & 51600 & sitoo \\
\hline Calatide (") & ment & $\leq 1200$ & $\leq 1200$ \\
\hline Flowride & mol & 56 & $\leq 12$ \\
\hline Toual Phosptorus (P) & mpl & 510 & 510 \\
\hline Ammoniar Nongen $\left(\mathrm{N} \cdot \mathrm{NH}_{4}{ }^{4}\right)$ & mol & 515 & 590 \\
\hline Nitrite-Nirogen $\left(\mathrm{N}-\mathrm{NO} \mathrm{O}_{3}\right)$ & mgt & 90,6 & 906 \\
\hline Nitrate-Nitrogen $(\mathrm{N}-\mathrm{N} O), 7$ & met & $\$ 20$ & 50 \\
\hline \multicolumn{4}{|c|}{ 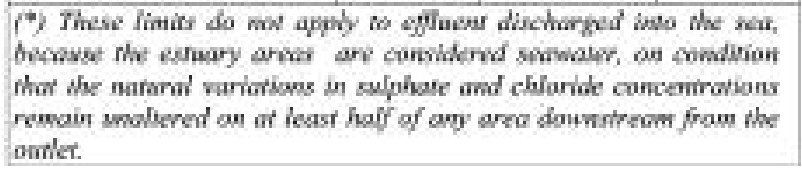 } \\
\hline
\end{tabular}

TABLE 1 - EC Directive 91/271 and EC Directive 91/676: Main maximum permitted levels of chemical and physical parameters regarding effluent discharges into surface waters or sewage systems.

\section{Materials and methods}

Experimental trials were conducted at the "Isola di Varano" Cooperative, an intensive on-shore fish farm in the country near Ischiatella (Foggia Province, Apulia, South Italy). The plant uses fresh and saltwater for the intensive growing out of eurialine species: bass (Dicentrarchus labrax), gilthead bream (Sparus auratus), White Seabream (Diplodus sargo), Bully (Mugil cephalus ) and Eel (Anguilla anguilla). The plant was built in 1990 and covers an area of about $2500 \mathrm{~m}^{2}$. It consists of: 18 growing out basins with an area of $60.0 \mathrm{~m}^{2}$ and an effective depth of $1.2 \mathrm{~m}$; one $77.4 \mathrm{~m} \mathrm{x}$ $4.0 \mathrm{~m}$ drainage canal which receives the effluent discharged directly from each tank (Fig. 1); one $138.0 \mathrm{~m}$ drainage canal for waste water (Canal No.1); one $171.0 \mathrm{~m}$ drainage canal for effluent (Canal No.2) which discharges directly into Lake Varano (Fig. 1); 4 basins for fry captured in the lagoon; a covered area with electric control panels; a deposit where fish is prepared for sale; an office. The reinforced concrete basins are $1.4 \mathrm{~m}$ deep and partially interred, with a central dividing hollow-brick wall $11.0 \mathrm{~m}$ long and $1.36 \mathrm{~m}$ high (Fig. 2). The water is oxygenated using liquid oxygen which is delivered to all the basins through a network of metal pipes from two pressurised tanks. It is then mixed with the water by "Ven- turi effect" and diffused by two horizontal floating paddle aerators, which together with vertical floating paddle aerators may also supplement oxygenation using atmospheric air. Water renewal in the plant is carried out partly using water taken directly from Lake Varano, and partly using well-water. Water is delivered to the basins by two pumps which together guarantee a supply of $40 \mathrm{l} / \mathrm{s}$.

The bottom of each basin slopes about $1 \%$ towards the water outlet and also contains a sludge pit $(8.0 \mathrm{~m}$ long, $95.0 \mathrm{~cm}$ wide, $20.0 \mathrm{~cm}$ deep) which collects solid sediments and is situated along the wall containing the outlet flow. When the plant is operating, water is discharged from each basin through a vertical pipe which has the inlet slightly higher than the maximum height of the solid waste in the sludge pit and two outlets: a TOP outlet (about $1.0 \mathrm{~m}$ from the bottom of the

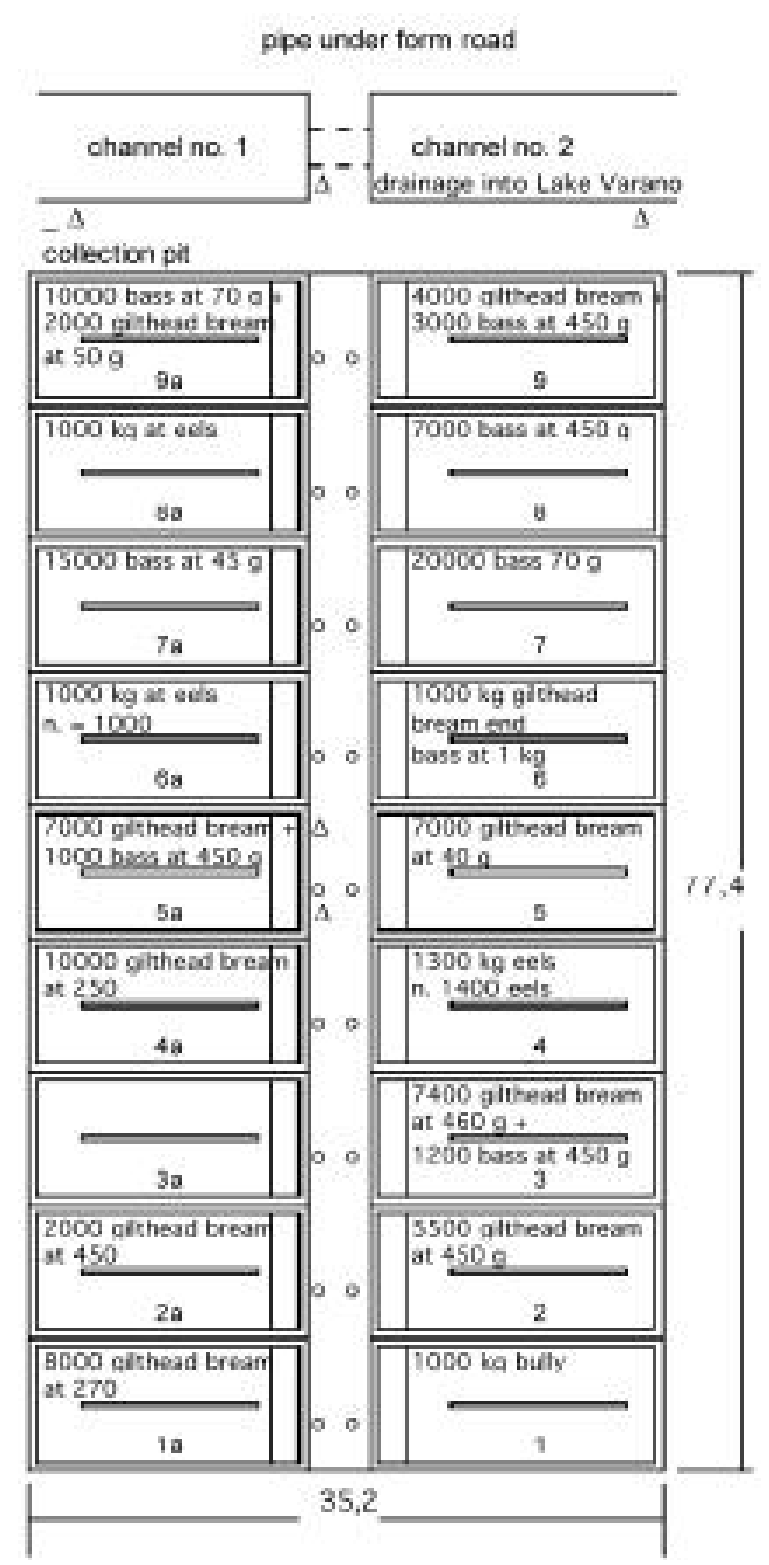

Fig. 1 - Diagram of the "Isola di Varano" Cooperative fish farm located in Ischiatella (Foggia Province, Apulia, South Italy). Image is drawn approximately to scale and measurements are in meters. $\mu$ : sample point. 
basin) and a bottom outlet (very near to the inlet). About twice a day the sediment in the sludge pit of each pond is drained out through the bottom outlet of the vertical pipe, therefore a sedimentation treatment separates large solids from the effluent of each basin before it is discharged (Fig. 2).

The water discharged from the basins flows into the concrete canal which is lower than the bottom of the basins and discharges into a collection pit (Fig. 1). From here the water flows into a $138.0 \mathrm{~m}$ effluent canal, then into a $70.0 \mathrm{~cm}$ diameter pipe under a farm road, and finally along a second $171.0 \mathrm{~m}$ effluent canal into Lake Varano (Fig. 1).

The first step of the present research programme was the characterization of effluent in conditions of maximum pollution, in order to define a suitable purification treatment.

The trials were carried out in the period 1-10 September 2008, when the plant reaches its production peak, and the sub-division of the biomass in the tanks is shown in Figure 1. One basin was selected for the trial and its effluent production was monitored for 10 days, while the main variables which influence effluent parameters were maintained as near constant as possible, as shown in Table 2.

Obviously it was not possible to impose the constant operating conditions of the monitored pond on all the other ponds during the course of the trials, but climatic factors, water temperature and production management during the trial period made it possible to establish similar stocking densities and feeding programmes throughout the entire plant.

No antibiotic treatments were carried out in the farm during the test period, or in the five days prior to the test period.

The parameters which influence the pollutant load in effluent water were maintained almost constant in Tank 4a (Fig. 1), and these parameters were also established in order to obtain the most critical pollution conditions; stocking density was at the highest levels and the maximum quantities of feed were administered because the water temperature made it possible to feed fish three times daily (Tab. 2).

In order to analyse effluent, water samples (10 litres per sample) were taken, every 2 days, from Basin 4a inlet and Basin 4a outlet; in the same way, every 2 days water samples were taken from the following areas: Farm outlet, Canal no.1 outlet, Canal no. 2 outlet. The goal was to evaluate any difference between polluting characteristics of the 4a basin's effluent (controlled) and the total effluent of the plant.

\begin{tabular}{|l|c|}
\hline Species & gilthead bream \\
\hline stocking density & $25 \mathrm{~kg}^{3}$ \\
\hline water temperature & $21.23^{\circ} \mathrm{C}$ \\
\hline water delivery & $401 / \mathrm{s}$ \\
\hline feed ration & $35 \mathrm{~kg} / \mathrm{day}$ \\
\hline
\end{tabular}

TABLE 2 - Technical parameters maintained constant in basin.4a (Fig. 1-2) during experimental tests.
Moreover, the analyses on the samples taken from the Canal no. 2 have been useful to evaluate any purifying effect due to the flow into the canal.

The following analyses were repeated three times for each sample: total suspended solids dried at 103$105^{\circ} \mathrm{C}(\mathrm{SST})$, chemical oxigen demand (COD), biochemical oxigen demand (5 days incubation at $20{ }^{\circ} \mathrm{C}$ : $\left.\mathrm{BOD}_{5}\right)$, ammonia - nitrogen $\left(\mathrm{N}-\mathrm{NH}_{4}+\right)$, nitrite - nitrogen $\left(\mathrm{N}_{-} \mathrm{NO}_{2}-\right)$, nitrate - nitrogen $\left(\mathrm{N}_{-} \mathrm{NO}_{3}^{-}\right)$, Total Phosphorus (TP), fecal particles (Escherichia coli). All analyses were conducted in accordance with the American Health Association (1998).

In the subsequent stage, according to the analitical results, laboratory tests were carried out, to evaluate the sedimentation speed, the dimensions and concentration of the suspended solids present in the studied effluent.

Sedimentation speed was determined in $1 \mathrm{dm}^{3}$ volume calibrated cylinders, into which the effluent was poured after being shaken. Evaluations were carried out on 5 cylinders for each sample of effluent taken.

Sedimentation speed was calculated by measuring the distance travelled and the time taken by each particle, developing an experimental procedure sufficiently reliable for the specific effluent, based on a test method suggested by other authors [Kevin 2000]. Sedimentation was observed for no more than 3 hours, because after this period it was no longer possible to see any particles falling.

During the sedimentation trials a sample of supernatant was taken from each cylinder after $60 \mathrm{~min}, 120$ min and $180 \mathrm{~min}$; this was done in order to determine the Total Suspended Solids, COD and $\mathrm{BOD}_{5}$. In addition, the volume of sludge accumulated was also measured.

The dimensions and concentration of the suspended solids present in the effluent studied were measured using an electron microscope - a Laborlux 12 by Leitz (Wetzalr-Germany) connected to a PC with a Leica QWin programme (Cambridge-England) - to analyse and process the images from the microscope. 50 slides were analysed for each sample; the slides consisted of 1 cell $0.5 \mathrm{~mm}$ deep with a total capacity of $20 \mu 1$.

For the same sample, each drop analysed was taken from a 1 litre container at different depths, after shaking the sample. The cell was filled using a sterile pipette and the microscope was set to $10 \mathrm{x}$.

The software measured and saved data regarding the length, width and depth of all the solids identified for each sample, expressed in $\mu \mathrm{m}$. The solids identified were then classified according to size and maximum dimension starting from the range 20-40 $\mu \mathrm{m}$; the last size class included solids with a maximum dimension greater than $500 \mu \mathrm{m}$.

Data were analysed by ANOVA using the GLN procedure SAS (1999-2000). Mean values were compared using the Student's test, and percentage values using the $\mu^{2}$ test. 


\section{Results}

The SST, COD and $\mathrm{BOD}_{5}$ levels of the incoming water are low, in accordance with the EU standards concerning effluent discharged into surface waters (Tab. 1), and the $\mathrm{BOD}_{5} / \mathrm{COD}$ ratio is slightly less than 0.5. However, the pollutant load (SST, COD and $\mathrm{BOD}_{5}$ ) of effluents from the farm and from Basin $4 \mathrm{a}$ is significantly higher $(\mathrm{P}<0.01)$ than in the incoming water (Tab. 3).

The $\mathrm{BOD}_{5}$ of the effluent is quite high, more than $60 \%$ of the COD, while specific production of the pollutant load in the monitored basin is more than 15 $\mathrm{g} \mathrm{COD} / \mathrm{kg}$ fish and over $10 \mathrm{~g} \mathrm{BOD}_{5} / \mathrm{kg}$ fish. The concentration of suspended solids in the effluent is greater $(\mathrm{P}<0.01)$ than in the incoming water: 18times higher at the outlet of the monitored basin and more than 15-times higher at the farm outlet.

The samples taken at the outlet from the first canal contain lower levels $(\mathrm{P}<0.01)$ of the already-mentioned effluent parameters than samples taken at the farm outlet, but these still exceed the legal limits (Tab. 1).

These limits are not met at the outlet of the second canal either (Tab. 1), although here the SST concentration is 5-6 times lower, and COD and $\mathrm{BOD}_{5}$ are effectively halved (Tab. 3). Finally, nitrite, nitrate, phosphate and ammonia contents were tested and found to be within the legal limits.

Ammonia, Nitrite, Nitrate and Phosphorus contents increase between inlet and outlets, but they are always quite lower than the minimum level allowed by law. Escherichia coli content is always very low and does not increase between inlet and outlets (Tab. 3).

These above mentioned concentrations differ sig-

\begin{tabular}{|c|c|c|c|c|c|}
\hline Pieandeter & Inint & $\begin{array}{l}\text { Outhes } \\
\text { frem } \\
\text { basin }\end{array}$ & $\begin{array}{l}\text { Flank } \\
\text { ouslet }\end{array}$ & $\begin{array}{l}\text { Finat } \\
\text { cianal }\end{array}$ & $\begin{array}{l}\text { Secorad } \\
\text { conal }\end{array}$ \\
\hline $\begin{array}{l}\text { SST } \\
\text { Alegal finit } 40 \\
\text { moil) }\end{array}$ & $\begin{array}{l}30.40 \pm \\
1.52^{\wedge}\end{array}$ & $\begin{array}{l}631 . A 5 \pm \\
23.79^{\circ}\end{array}$ & $\begin{array}{l}5.32 .92= \\
21.32\end{array}$ & $\begin{array}{l}418.34 \pm \\
11.73^{\circ}\end{array}$ & $\begin{array}{l}102.54 \pm \\
4.95^{4}\end{array}$ \\
\hline $\begin{array}{l}\text { COD } \\
\text { (Lead finit } 160 \\
\text { mail) }\end{array}$ & $\begin{array}{l}59.50= \\
4.38^{\circ}\end{array}$ & $\begin{array}{l}379.10= \\
21.39^{\mathrm{n}}\end{array}$ & $\begin{array}{l}151.22= \\
29.61^{10}=\end{array}$ & $\begin{array}{l}310.23 \pm \\
19.87^{\circ}\end{array}$ & $\begin{array}{l}103.50 \pm \\
11.61^{8}\end{array}$ \\
\hline $\begin{array}{l}\text { BOD, } \\
\text { Aleall finit } 40 \\
\text { mals }\end{array}$ & $\begin{array}{l}18.00= \\
0.71^{*}\end{array}$ & $\begin{array}{l}252.41= \\
19.26^{\circ}\end{array}$ & $\begin{array}{l}220.80= \\
11.21^{\circ}\end{array}$ & $\begin{array}{l}165.60= \\
15.40^{2}\end{array}$ & $\begin{array}{l}111.16 \pm \\
11.22^{2}\end{array}$ \\
\hline $\mathrm{BND}, \mathrm{COD}$ & $\begin{array}{l}0.31 \pm \\
0.0113 \\
0\end{array}$ & $\begin{array}{r}0.67 \neq \\
0.0219^{\circ}\end{array}$ & $\begin{array}{l}0.63 \pm \\
0.0273\end{array}$ & $\begin{array}{l}0.53 \pm \\
0.023^{6}\end{array}$ & $\begin{array}{l}0.562 \pm \\
0.0244^{2}\end{array}$ \\
\hline $\begin{array}{l}\text { Escherichis coli } \\
\text { deyal linit } \\
500 \text { UFCios } \\
\text { mil }\end{array}$ & $\begin{array}{l}10 \pm \\
0.65\end{array}$ & $\begin{array}{l}10 \pm \\
081^{4}\end{array}$ & $\begin{array}{l}10= \\
6.95\end{array}$ & $\begin{array}{l}10 \pm \\
0.59^{2}\end{array}$ & $\begin{array}{l}10 \pm \\
0.56^{A}\end{array}$ \\
\hline $\begin{array}{l}\text { Ammoaia: } \\
\text { Nitrogen } \\
\text { Alegal limin } 15 \\
\text { mgly }\end{array}$ & $\begin{array}{l}0.08 \pm \\
00001 \\
t\end{array}$ & $\begin{array}{r}0.32+ \\
0.0695^{\circ}\end{array}$ & $\begin{array}{l}0.43 t \\
0.0078\end{array}$ & $\begin{array}{l}0.37 z \\
0.012^{6}\end{array}$ & $\begin{array}{r}0.44 \pm \\
0.8074^{6}\end{array}$ \\
\hline $\begin{array}{l}\text { Nitrie-Nitrogen } \\
\text { deged imin } 0.5 \\
\text { mgly }\end{array}$ & $\begin{array}{l}0084 \\
00001 \\
4\end{array}$ & $\begin{array}{c}0.324 \\
0.004 T^{6}\end{array}$ & $\begin{array}{l}0.56 \mathrm{k} \\
0.014^{c}\end{array}$ & $\begin{array}{l}0.494 \\
0.00 ?^{\circ}\end{array}$ & $\begin{array}{r}0.400^{\circ} \\
0.911^{6}\end{array}$ \\
\hline $\begin{array}{l}\text { Nitrate- } \\
\text { Nitrogen } \\
\text { A.egal linit 20 } \\
\text { irtyil) }\end{array}$ & $\begin{array}{l}0.01+2 \\
000002 \\
2\end{array}$ & $\begin{array}{c}0.07+ \\
0.00 \mathrm{t} T^{8}\end{array}$ & $\begin{array}{l}0.07 \mathrm{i} \\
6.0015^{\circ}\end{array}$ & $\begin{array}{l}0.11+ \\
0.0684^{\circ}\end{array}$ & $\begin{array}{c}0.08+ \\
0.000 B^{\circ}\end{array}$ \\
\hline $\begin{array}{l}\text { Total } \\
\text { Phosphmus } \\
\text { Aegal limil } 10 \\
\text { mals }\end{array}$ & $\begin{array}{l}0.004 \\
0.00^{*}\end{array}$ & $\begin{array}{l}9,144 \\
0.0608^{8}\end{array}$ & $\begin{array}{l}0.372 \\
6.0075^{5}\end{array}$ & $\begin{array}{l}0.614 \\
0.011^{\circ}\end{array}$ & $\begin{array}{r}0.454 \\
0.6084^{2}\end{array}$ \\
\hline
\end{tabular}

TABLE 3 - Concentrations of the main pollution parameters. * Every value has been obtained as an average of analysis carried out on 5 samples, repeating the analysis on each sample three times. On row: $A, B, C, D, E ; P<0.01 ; a, b ; P<0.05$.

nificantly $(\mathrm{P}<0.01)$, according to the site where they were found.

The sedimentation trials showed maximum sedimentation speeds which varied between 6.51 and $46.13 \mathrm{~mm} / \mathrm{s}$ and minimum speeds of 2.53-26.79
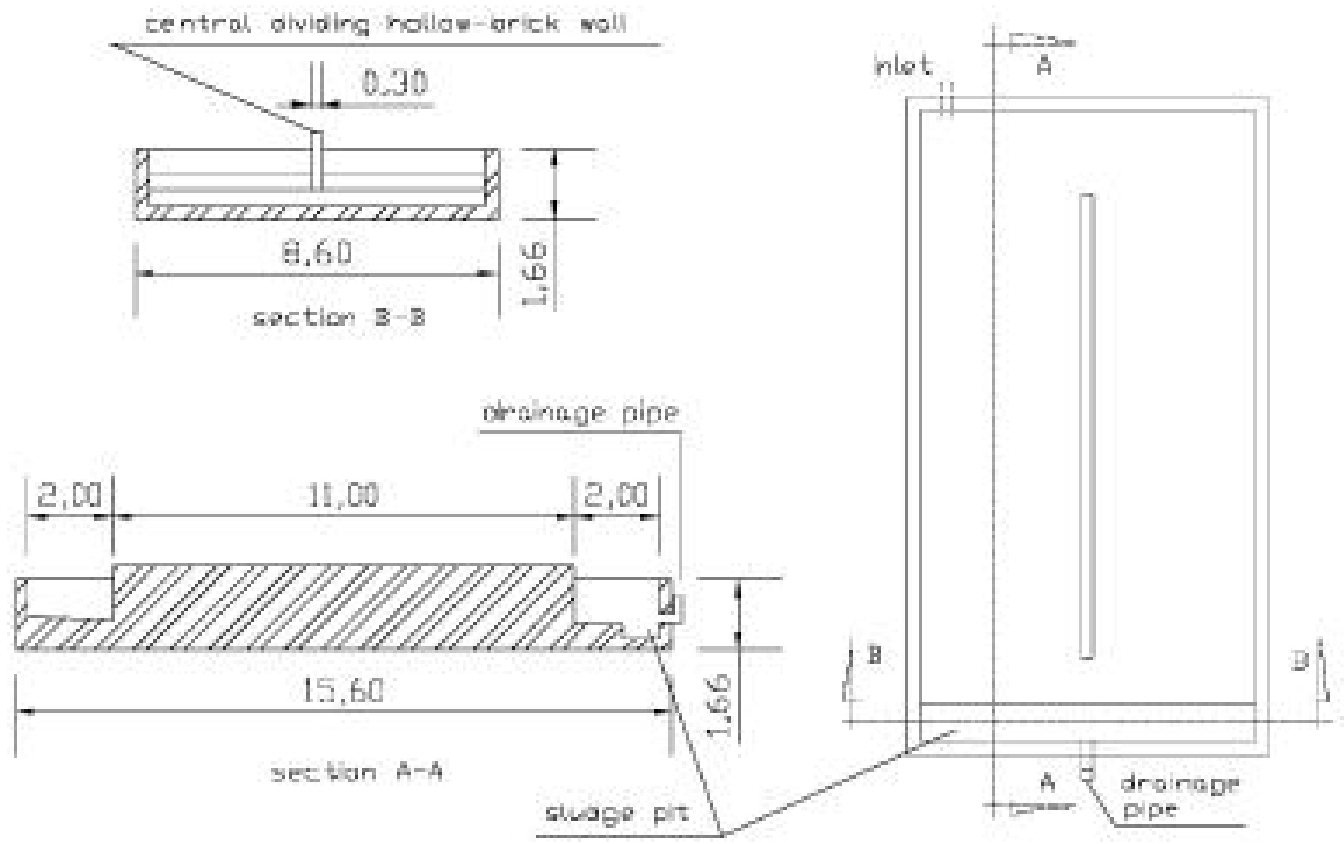

Fig. 2 - Schematic plan of the reinforced concrete basin. The image is approximately drawn to scale and the measurements are in meters. 


\begin{tabular}{|c|c|c|c|}
\hline $\begin{array}{l}\text { Sodimentation } \\
\text { tirne (min) }\end{array}$ & $\begin{array}{l}\text { Maxirnum } \\
\text { nodimentidion speods } \\
\text { (mm/s) }\end{array}$ & $\begin{array}{l}\text { Minimum } \\
\text { sedinentation apood } \\
\text { (numbs) }\end{array}$ & $\begin{array}{l}\text { Sladge } \\
\text { volume } \\
\text { imlitm't' }\end{array}$ \\
\hline 60 & $46.13 \pm 5.89 \mathrm{~A}$ & $26.79 \pm 3.93 \mathrm{~A}$ & $\begin{array}{l}30.51= \\
1.39 \mathrm{~A}\end{array}$ \\
\hline 120 & $13,10<0.758$ & $9.54 \div 1.158$ & $\begin{array}{l}39.79 \mathrm{~A} \\
2.03 \mathrm{~B}\end{array}$ \\
\hline 150 & $6.51=0.94 \mathrm{C}$ & $2.53 \pm 0.23 c$ & $\begin{array}{l}48.74= \\
1.076\end{array}$ \\
\hline
\end{tabular}

TABLE 4 - Summary of the sedimentation speeds (mean \pm S.D.) (average values of 60 observations*). On column: $A$ vs $B$ vs $C, P<0.01$.

$\mathrm{mm} / \mathrm{s}$, with sludge production between 30.51 and $48.74 \mathrm{ml} / \mathrm{dm}^{3}$ (Tab. 4). It should be noted that during the trial time (180 min), speeds were quite variable, showing great variability in the nature and size of the solids present in the effluent. Therefore, in order to obtain homogeneous results, the trial period was subdivided into three partial times of $60 \mathrm{~min}$. During each of these periods the average, minimum and maximum sedimentation speeds of solids were calculated, sludge volume was recorded and the effluent parameters of the supernatant were determined.

Maximum sedimentation speeds were achieved in the first $60 \mathrm{~min}$ of treatment: $46.13 \mathrm{~mm} / \mathrm{s}$ being the maximum speed and $26.79 \mathrm{~mm} / \mathrm{s}$ the minimum (Tab. 4). Between $60 \mathrm{~min}$ and $120 \mathrm{~min}$ the maximum speed slows down considerably $(\mathrm{P}<0.01)$, approaching the minimum speed (Tab. 4).

The most noticeable reduction is found in the last $60 \mathrm{~min}$, with a further narrowing of the difference between the maximum and minimum speeds: the maximum speed was $6.51 \mathrm{~mm} / \mathrm{s}$ and the minimum was $2.53 \mathrm{~mm} / \mathrm{s}$ (Tab. 4).

Similarly, there is a very great reduction $(\mathrm{P}<0.01)$ in the pollutant load in the first $120 \mathrm{~min}$ (Tab. 5). In this period, the SST is reduced by $78-79 \%$, COD by $42-47 \%$ and the $\mathrm{BOD}_{5}$ by about $53 \%$; this can be compared with total reduction at the end of $180 \mathrm{~min}$, which was respectively $81.3-86.8 \%, 49-55 \%$ and 59$66.8 \%$.

The graphs in Figures 3-4 show the most representative sedimentation speed trends of solid particles in the effluent versus time. This makes it possible to understand how the settling process takes place. It can be seen that speed tends to increase in the first stage of sedimentation in the calibrated cylinder, and then diminishes until the minimum speeds are reached in the final stage. In the last $60 \mathrm{~min}$ of treatment it is much less evident, and speed curves are much less pronounced.

When the effluent samples were viewed under the microscope, the distribution of solids was seen before and after sedimentation treatment (Tab. 6). These data refer to the most potentially polluting conditions, which correspond to the effluent from Basin 4a, because these conditions are the basis for calculations

\begin{tabular}{|c|c|c|c|c|}
\hline Efthoed & $\begin{array}{l}\text { SST ingl) } \\
\text { (Legal linit: } \\
40 \text { mal) }\end{array}$ & $\begin{array}{l}\text { CODimpl) } \\
\text { (thegal liait: } \\
\mid 60 \mathrm{mpl})\end{array}$ & 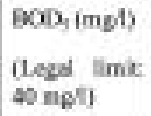 & $\begin{array}{l}100 \mathrm{y} / \\
\mathrm{COD}\end{array}$ \\
\hline Busin oullet & $\begin{array}{l}631.40= \\
23.97 \mathrm{~A} \\
\ldots\end{array}$ & $\begin{array}{l}3 \pi .00 \mathrm{~A} \\
21.19 \mathrm{~A} \\
\ldots\end{array}$ & $\begin{array}{l}252.61 \\
19.03 \mathrm{~A} \\
\ldots\end{array}$ & $\begin{array}{l}0.67 \mathrm{t} \\
6.02 \mathrm{~B} .\end{array}$ \\
\hline Plant ouslat & $\begin{array}{l}523.60 \\
21021\end{array}$ & $\begin{array}{l}351.80 \\
29.491\end{array}=$ & $\begin{array}{l}220.93 \\
11,321\end{array}=$ & $\begin{array}{l}0.63 \pm \\
0.051 .\end{array}$ \\
\hline $\begin{array}{l}\text { Besis outlat } \\
\text { (ander } 60 \mathrm{~min} \text { ) }\end{array}$ & $\begin{array}{l}301.00+6.32 \\
\mathrm{~B}\end{array}$ & $\begin{array}{l}255.00+9.70 \\
8 a\end{array}$ & $\begin{array}{l}18330+8.67 \\
\mathrm{~B}\end{array}$ & $\begin{array}{r}0.72 \mathrm{~L} \\
0.06 \mathrm{~A} \\
\text { ns. }\end{array}$ \\
\hline 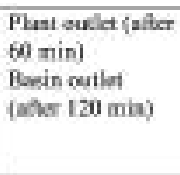 & $\begin{array}{l}221.40 \pm 3.21 \\
\text { M } \\
183.50+3.27 \\
\text { C }\end{array}$ & $\begin{array}{l}236.00 \\
12.00 \mathrm{M} \\
215.20 \\
11.03 \mathrm{lb} \\
\end{array}$ & $\begin{array}{l}14160 \pm 737 \\
M \\
11680 \pm 6.10 \\
C \\
+\end{array}$ & $\begin{array}{l}0.60 \mathrm{x} \\
6.03 \mathrm{M} \\
0.54 \mathrm{~L} \\
9.02 \mathrm{~B} \\
\mathrm{n.5}\end{array}$ \\
\hline 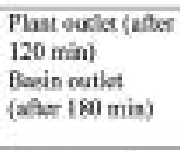 & $\begin{array}{l}105.20+3.19 \\
\mathrm{~N} \\
114.40+5.66 \\
\mathrm{D}\end{array}$ & $\begin{array}{l}185.00+9.37 \\
\mathrm{~N} \\
191.85+8.58 \\
\mathrm{C}\end{array}$ & $\begin{array}{l}94.80+534 \\
\mathrm{~N} \\
105.30 \pm 4.87 \\
\mathrm{D}\end{array}$ & $\begin{array}{r}0.51 \mathrm{t} \\
0.04 \mathrm{~N} \\
6.54 \mathrm{~L} \\
0.05 \mathrm{~B} \\
.\end{array}$ \\
\hline $\begin{array}{l}\text { Piant ouskt (aitue } \\
150 \mathrm{~min} \text { ) }\end{array}$ & $a_{0}^{68.20+3.42}$ & $\begin{array}{l}19820 \\
11.800\end{array}$ & $\begin{array}{l}73.00+3.16 \\
0\end{array}$ & $\begin{array}{l}9.46 \% \\
0.020\end{array}$ \\
\hline
\end{tabular}

TABLE 5 - Results of sedimentation tests on effluent (mean \pm S.D.). Every value has been obtained as average of analysis carried out on n. 5 samples, repeating the analysis on each sample three times. **, $A$ vs $B$ vs $C$ vs $D ; L$ vs $M$ vs $N$ vs $O ; P<$ 0.01 ; *, a vs $b, P<0.05 ;$ n.s., not significantly.

regarding the design of a mechanical filter.

It must be pointed out that most of the solids in the effluent studied had one dimension which was greater than the others. For this reason, of the three dimen-
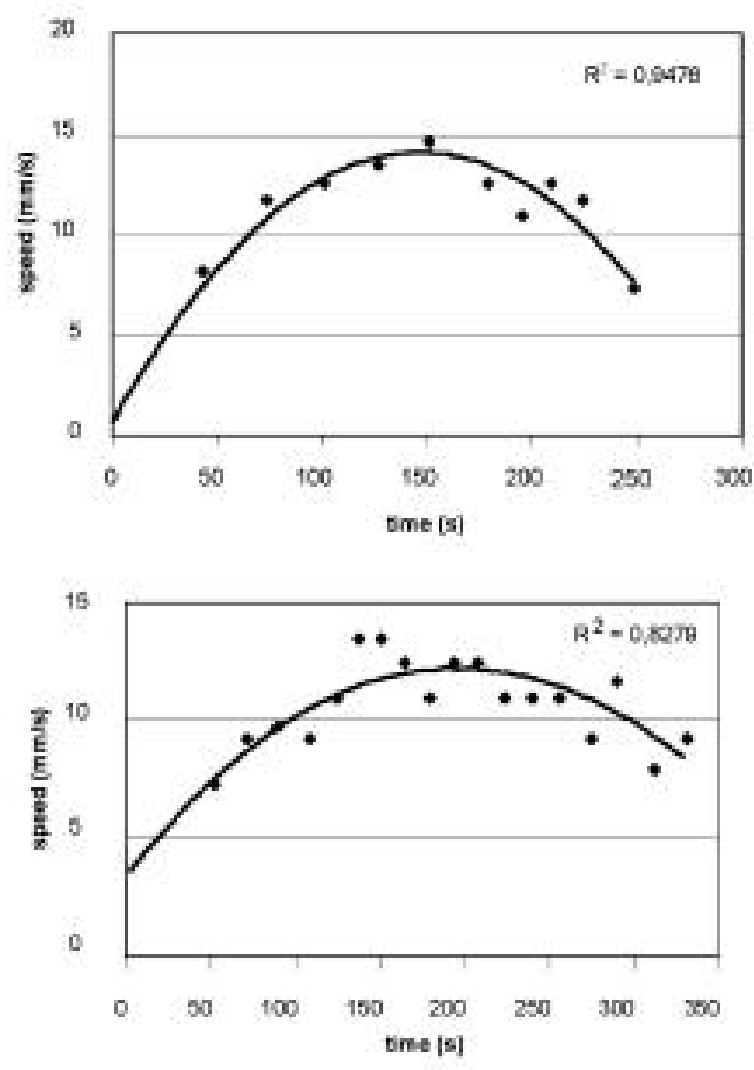

Fig. 3 - Representative sedimentation speed of solids over time. Test duration from $60 \mathrm{~min}$ to $120 \mathrm{~min}$. 

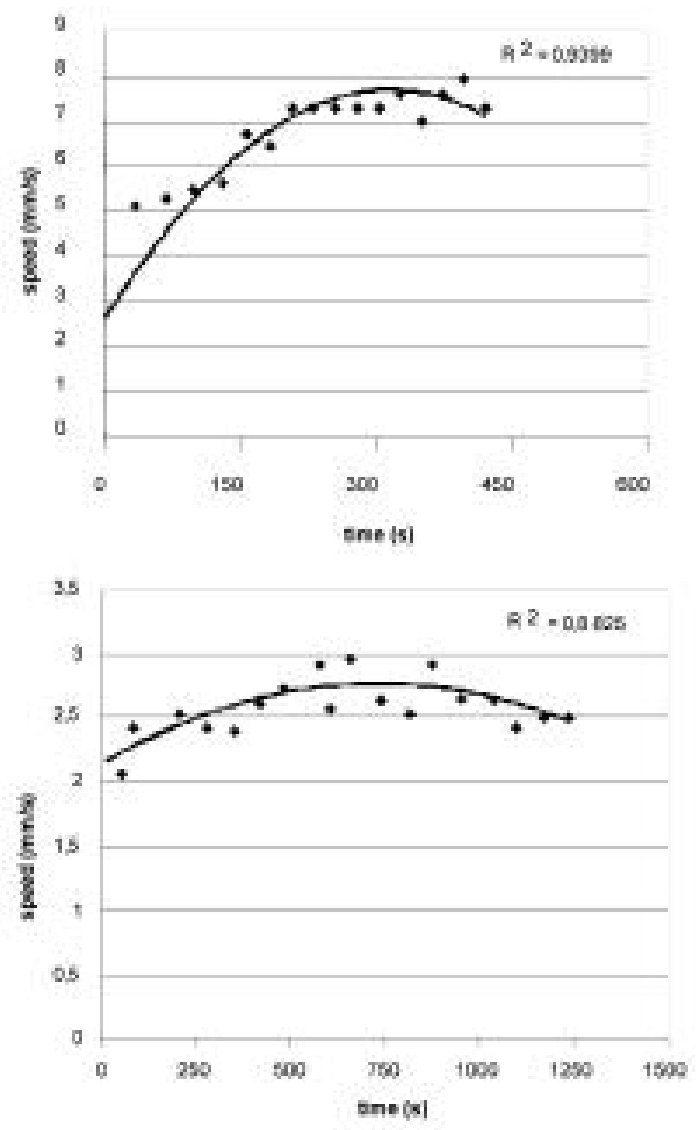

Fig. 4 - Representative sedimentation speed of solids over time. Time of test from $120 \mathrm{~min}$ to $180 \mathrm{~min}$.

sions measured for every solid identified, the greatest was considered the most important, because the mesh of a mechanical filter should trap the solid along this dimension.

Generally the distribution of solids is significantly different depending upon the various categories of dimension after a sedimentation period of 120 and 180 minutes. Whereas, after 60 minutes the values corresponding to the $301-350 \mu \mathrm{m}$ size class and the following class differ significantly (4.39 vs $11.40 \%$; $\mathrm{P}<$ $0.05)$.

The effluent studied presents an average concentration of suspended solids of $631.45 \mathrm{mg} / \mathrm{l}$ (Tab. 3), the largest percentage of which (about $19 \%$ ) is made up of particles with an average maximum dimension of about $556.0 \mu \mathrm{m}$, i.e. included in the over $500 \mu \mathrm{m}$ size class (Tab. 6). During sedimentation treatment, the total percentage of solids with a maximum dimension of $200 \mu \mathrm{m}$ to more than $500 \mu \mathrm{m}$ drops to $47 \%$ after 60 min (with partial levels referring to the single size classes which vary from 3-7\%), to $29 \%$ after $120 \mathrm{~min}$ (with partial levels referring to the single size classes which vary from $1-3 \%$ ) and to $11 \%$ after $180 \mathrm{~min}$, with partial values referring to the single size classes not exceeding $4 \%$ (Tab. 6).

However, the percentage of particles with maximum dimensions of 100-200 $\mu \mathrm{m}$, remains the same or even increases during the first $120 \mathrm{~min}$, and only in

\begin{tabular}{|c|c|c|c|c|}
\hline $\begin{array}{l}\text { Size clases } \\
\text { (am) }\end{array}$ & $\begin{array}{l}\text { Untreaited } \\
\text { Efflluent }\end{array}$ & $\begin{array}{c}\text { EMluent } \\
\text { after } 60 \\
\min \end{array}$ & $\begin{array}{l}\text { Emluent } \\
\text { after } 120 \text { min }\end{array}$ & $\begin{array}{c}\text { Emluent } \\
\text { after } 180 \\
\text { min }\end{array}$ \\
\hline $20-40$ & $3.78 \mathrm{CDC} C$ & 8,77 & $2066 \mathrm{~A}$ & $3191 \mathrm{~A}$ \\
\hline$+1+60$ & 1.680 & 5,26 & 7.448 & $15,96 \mathrm{Bab}$ \\
\hline $81-80$ & $5.04 \mathrm{CD}$ & 8,77 & $14.88 \mathrm{ABa}$ & $11.70 \mathrm{~B}$ \\
\hline $81-100$ & $1.26 \mathrm{D}$ & 5,26 & $5.78 \mathrm{BCb}$ & $7.45 \mathrm{BCb}$ \\
\hline $101-120$ & $1.26 \mathrm{D}$ & $\cdot$ & - & $4.25 \mathrm{~B}$ \\
\hline $121-140$ & $1.26 \mathrm{D}$ & 5.26 & 4.13 & $1.06 \mathrm{~B}$ \\
\hline $141-160$ & $5.46 \mathrm{CD}$ & 7,89 & $6.66 \mathrm{BCb}$ & $5.32 \mathrm{BCe}$ \\
\hline 161.180 & $3.36 \mathrm{CDC}$ & 6,14 & $5.78 \mathrm{BCb}$ & $5.32 \mathrm{BCc}$ \\
\hline $181-200$ & $3.36 \mathrm{CDC}$ & 5,26 & $4.96 \mathrm{C}$ & $5.32 \mathrm{BCC}$ \\
\hline $201-250$ & $9.66 \mathrm{BC}$ & 7,02 & $4.13 \mathrm{C}$ & $5.32 \mathrm{BCc}$ \\
\hline $251-300$ & $7,56 \mathrm{BCab}$ & 6,14 & $4.13 \mathrm{C}$ & 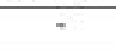 \\
\hline $301-350$ & $8.82 \mathrm{BCa}$ & 4,396 & $4.13 \mathrm{C}$ & 7 \\
\hline 351.400 & $12.18 \mathrm{AB}$ & 11,402 & $4.96 \mathrm{C}$ & $6.38 \mathrm{BCc}$ \\
\hline $401-450$ & $8.40 \mathrm{BK}=\mathrm{a}$ & 6,14 & $4.13 \mathrm{C}$ & - \\
\hline $451-500$ & $7,14 \mathrm{BC}$ & 5,26 & $4.13 \mathrm{C}$ & - \\
\hline$>500$ & $19.75 \mathrm{~A}$ & 7,02 & $4,13 \mathrm{C}$ & 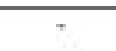 \\
\hline
\end{tabular}

TABLE 6 - Distribution percentage of the solids during sedimentation treatment*. On column, different letters indicate significant differences, capital letters for $P<0.01$ or lower case for $P<0.05$. * All data were each obtained as an arithmetic average of 80 observations.

the last 60 min diminishes by about $8 \%$ to around $2.3 \%$. Finally, the particles with a maximum dimension of 20-100 $\mu \mathrm{m}$ are a percentage of the total which tends to increase during the sedimentation treatment (Tab. 6).

\section{Discussion}

The pollutant load of the effluent was considerably higher than that of the incoming water, and this was mostly due to the high stocking density and administration of large quantities of feed. On the other hand, the production conditions and feeding programme established during the test period can only be kept up for 4 months of the year.

The high $\mathrm{BOD}_{5} / \mathrm{COD}$ ratio in this effluent indicates organic matter as the main component of the pollutant load. The nitrite, nitrate, phosphate and ammonia levels remain within legal limits, so it can be said that the effluent contains a large percentage of organic matter in the form of suspended solids; this applies to effluent from the whole farm, and especially the monitored basin.

In fact, tests on the waste water from the monitored basin gave results which are substantially comparable with the results regarding the waste water from the entire farm, although in the other basins it was not possible to control and maintain entirely constant the parameters which could effect the pollutant load.

Therefore, although the effluent examined derives from a high level of metabolic activity and the maxi- 
mum stocking concentration, it requires a purification treatment which can reduce the pollutant load to within the legal limits. The characteristics of the effluent suggest a treatment which separates the suspended solids, such as sedimentation or mechanical filtration.

Noticeable reductions in SST, COD and $\mathrm{BOD}_{5}$ are found in the effluent at the outlet of the second canal and these may also be attributed to a sedimentation process of the suspended solids taking place as the effluent travels along this canal.

However, it is evident that the efficiency of this process is not optimum in these canals, in relation to the length and depth of the canal, as well as to the ratio turbid speed/sedimentation speed. So determination of the solid sedimentation speed is of vital importance for designing a sedimentation basin.

The curves representing sedimentation speed over time (Fig. 4-5), show a trend confirming the results of other trials involving effluents with similar physical and chemical characteristics [Amirante 1991; Wong 2000; Jones 2001]; this trend is mainly due to the greater concentration of solids in the final part of the calibrated cylinder in the first 120 min of the settling process. However, in the last $60 \mathrm{~min}$ of treatment the heaviest particles have already settled and created a quite compact layer of sediment, so that only the lightest particles, usually with a flaky consistency, settle at a more or less constant speed (Tab. 5). In confirmation of this, there is much less sedimentation of suspended solids in the final $60 \mathrm{~min}$ than in the first $120 \mathrm{~min}$ (Tab. 5).

It can be seen that the sedimentation process carried out in the laboratory was only just sufficient to bring the farm effluent within the legal limits (Tab. 5). However, the effluent from the monitored basin had a greater pollutant load at the outset and still had higher SST, COD and $\mathrm{BOD}_{5}$ levels than those permitted for waste discharged into surface water (Tab. 5). In this case, perhaps mechanical filtration may be a more suitable treatment for this effluent.

The analysis of solid distribution in the effluent shows that over $60 \%$ of the total solids present are particles with a maximum dimension ranging from $200 \mu \mathrm{m}$ to more than $500 \mu \mathrm{m}$ (Tab. 6). So it is quite obvious that only the very large and heavy solids actually sediment in the basin's sludge pit (Fig. 3).

The solids measuring $200 \mu \mathrm{m}$ to over $500 \mu \mathrm{m}$ are separated more efficiently by sedimentation treatment, so that the total percentage falls to $6 \%$ after 180 min (Tab. 6). However, the $100 \mu \mathrm{m}$ to $200 \mu \mathrm{m}$ particles sediment quite slowly and their total percentage diminishes noticeably only in the final $60 \mathrm{~min}$ (Tab. 6). Finally, the $20 \mu \mathrm{m}$ to $100 \mu \mathrm{m}$ particles do not sediment, and therefore tend to increase as a percentage of the solids in the effluent (Tab. 6).

Likewise, the total of suspended solids in the effluent tends to diminish during sedimentation, falling from $631.45 \mathrm{mg} / \mathrm{l}$ to $114.18 \mathrm{mg} / \mathrm{l}$ (Tab. 6). Since these percentages indicate a much lower solid content than at the outset, it can be said that the particles measur- ing over $200 \mu \mathrm{m}$ have effectively disappeared after the sedimentation treatment.

If a mechanical filter were to be used to separate solids, and reduce the pollutant load in this particular effluent to lower levels than that achieved using sedimentation, it would require a mesh with a pore size of no more than $80 \mu \mathrm{m}$. A $50 \mu \mathrm{m}$ mesh would be considered sufficient for any critical situation caused by the presence of filiform solids which can pass through a filter despite having one dimension which is larger than the mesh. If these solids were a relatively large percentage of the total, even a mechanical filter might prove not provide a sufficient purification treatment.

\section{Conclusions}

Aquaculture can only take place in a system which perfectly respects the balance of nature. This is obviously also true of intensive installations, which must conform to methods for reducing all types of pollution.

The research confirmed that it is possible for intensive systems to have operating conditions - often concentrated in short periods of the production cycle which require waste water treatment. In order to obtain reduced $\mathrm{COD}$ and $\mathrm{BOD}_{5}$, this treatment may consist of the simple separation of suspended solids.

Mechanical filtration treatment may suit the specific requirements of the farm used for the experimental trials. The analysis of effluent showed a pollutant load with high concentrations of suspended organic matter, which tends to noticeably increase the $\mathrm{BOD}_{5} / \mathrm{COD}$ ratio.

In general, the solution must be chosen on the basis of the following technical considerations, some of which derive from the results of the present study.

- Several studies have shown that the pollutant load of the effluent studied is seasonal, therefore it is not always necessary to have purification treatment all year round, but only in periods when feeding levels are at a maximum and at times when the basins are being cleaned.

- The suspended solids sediment at very variable speeds, and some of these may remain suspended even $3 \mathrm{~h}$ after treatment.

- A filter requires less space than does a sedimentation basin.

- The cost of installing a mechanical filtration system is quite low, and running costs depend on how it is used. On the other hand, the cost of a sedimentation basin depends on the natural resources and area available and on the possibility of farming less valuable species like grey mullet (Mugil cephalus) in the same fish farm, using some of the waste water from the more valuable species.

The present research has shown that an effluent channel is not as efficient in reducing the pollutant load of waste water as sedimentation treatment. The results of sedimentation trials have shown - for a pe- 
riod of about 3 hours - minimum and maximum solid particle sedimentation speeds of $2.56 \mathrm{~mm} / \mathrm{s}$ and 46.8 $\mathrm{mm} / \mathrm{s}$ respectively, which should be considered when deciding the water speed and the dimensions of basins for this type of effluent.

Another consideration is that when the pollutant loads are high, like those studied, sedimentation must be integrated with chemical and physical adjuvants, in order to further improve the separation of solids.

Finally, electron microscope-assisted classification of solids proved quite representative of real distribution and this was shown also by the correspondence between the size classes defined and the dimensions of the sedimented particles. Therefore, this method may be proposed for designing, rather than for checking, filtration plants for effluent from other intensive fish farms.

\section{Acknowledgements}

The Authors wish to thank Dr. E. CECI for his work in carrying out some of the chemical analyses on waste water, and the "Isola di Varano" Cooperative for allowing the study and for collaborating on the experimental trials. They would also like to thank Prof. G.F. PASSANTINO, the Coordinator of the "Anatomy of Domestic Animals II" section of the Di.SBA Dept. of the Faculty of Vetrinary Medicine of Bari, for authorising the use of the scientific laboratory for size characterisation of the suspended solids, and Dr. A. CIANCIOTTA, graduate technician in charge of the "Anatomy of Domestic Animals II" for co-ordinating and helping with the morphological analysis of the suspended solids.

\section{References}

American Public Healt Association, American Water Works Association and Water Environment Federation. Standard Methods for the Examination of Water and Wastewater, 20th Ed.. American Water Works Association, Water Environment Federation, and American Public Healt Association, Washington, DC, USA 1998.

Amirante P., Bianchi B., Di Renzo G.C. Depurazione dei reflui di industrie di macellazione avicola con recupero della sostanza organica a scopo mangimistico. Atti del $3^{\circ}$ seminario della II Sezione A.I.G.R. "Insediamenti Zootecnici e Protezione dell'Ambiente", Udine, 1991.

Bianchi B., Montel G.L. Caratterizzazione dei reflui di un impianto intensivo on-shore per la definizione di un trattamento di filtrazione. Atti della Giornata di lavoro "Innovazioni meccanico-impiantistiche per l'agricoltura, l'agro-industria e l'acquacoltura", Anacapri (NA), pp. 129-139. CD-ROM printed. ISBN 88-89010-01-0, 2003.

Boyd C.E.. Water quality in ponds for Aquaculture. Alabama Agricultural Experiment station, Auburn University, Auburn, Alabama, 1990.

Dosdat Antoine, Gaumet Frédéric \& Chartois Hervé. Marine Aquaculture Effluent Monitoring: Methodological Approach to the Evalutation of Nitrogen and Phosphorus Execretion by fish. Aquacultural Engineering, 14, 59-84, 1994.
Dumas A., Leliberté G., Lessard P., Noe J. Biotreatment of fish farm effluents using the cyanobacterium Phormidium Bohneri. Aquacultural Engineering, 17, 57-68, 1998.

Kevin B. Wong, Raul H. Piedrahita. Settling velocity characterization of aquacultural solids. Aquacultural Engineering 21, 233-246, 2000.

Jones A.B., Dennison W.C., Preston N.P. Integrated treatment of shrimp effluent by sedimentation, oyster filtration and macroalgal absorption: a laboratori scale study. Aquaculture 193, 155-178, 2001.

McIntosh Dennis, Fitzsimmons Kevin. Characterization of effluent from an inland, low salinity shrimp farm: what contribution could this water make if used for irrigation. Aquacultural Engineering, 27, 147-156, 2003.

Ross R.M., Watten B.J., Krise W.F., Di Lauro M.N. 1995. Influence of tank design and hydraulic loading on the bheavior, growth, and metabolism of rainbow trout $(\mathrm{On}$ corhynchus mykiss). Aquacultural Engineering 14, 29-47.

SAS: SAS sas/stat TM Guide for Personal computers, Version 8.1 Edn. SAS INstitute Inc., Cary, NC, USA (19992000).

Suresh Arul V. \& Kwei Lin C. Effect of Stocking Density on Water Quality and Production of Red Tilapia in a Recirculated Water System. Aquacultural Engineering 11, 1-22, 1992.

Ziemann, D. A., Walsh, W. A., Saphore, E. G., Fulton-Bennet, K. A Survey of water quality characteristics of effluent from Hawaiian aquaculture facilities. J World Aquacult. Soc. 23, 180-191, 1992.

\section{SUMMARY}

The pollutant load was monitored in an intensive on-shore plant; evaluation especially concerned one basin, during a period of time in which the water temperature $\left(21-23^{\circ} \mathrm{c}\right)$, the stocking density $\left(25 \mathrm{~kg} / \mathrm{m}^{3}\right)$, the loading and unloading flow $\left(40 \mathrm{dm}^{3} / \mathrm{s}\right)$ remained steady at the highest values.

The results show that the maximum pollution levels are characterized by high concentrations of suspended organic materials, as well as by high $\mathrm{BOD}_{5} / \mathrm{COD}$ rates; moreover, more than $60 \%$ of the suspended solid waste consists of particles with a maximum dimension ranging from $200 \mu \mathrm{m}$ to more than $500 \mu \mathrm{m}$. Tests show that an effluent channel is not efficient in reducing the pollutant load of waste water.

The laboratory sedimentation trials showed - for a period of about 3 hours - minimum and maximum solid particle sedimentation speeds of $2.56 \mathrm{~mm} / \mathrm{s}$ and 46.8 $\mathrm{mm} / \mathrm{s}$ respectively, which should be considered when deciding the turbid speed and the dimensions of basins for this type of effluent. In any case, the sedimentation process carried out in the laboratory was only just sufficient to bring the farm effluent within the legal limits. Therefore a mechanical filtration treatment may suit the specific requirements of the farm waste water used for the experimental trials. A $50 \mu \mathrm{m}$ mesh would be considered sufficient for any critical situation.

Keywords: On-shore intensive fish farm; Waste water; Polluting characterization; Purifying treatment; Sedimentation; Filtration. 